\title{
Danıştay ve Askeri Yüksek İdare Mahkemesi Kararları Çerçevesinde MANEVI TAZMINATA FAİZ YÜRÜTÜLMESİ SORUNU
}

\author{
The Matter of Calculating Interest to Compensation for Mental \\ Anguish According to the Decisions of Council of State and High \\ Military Administrative Court
}

Yrd. Doç. Dr. Gürsel KAPLAN*

\begin{abstract}
GİRIŞ, I.MANEVİ TAZMINATIN NITELİĞİ ve İŞLEVI, II.DANIŞTAY'IN UYGULAMASI, III.ASKERİ YÜKSEK İDARE MAHKEMESI'NIN UYGULAMASI, SONUÇ
\end{abstract}

\section{ÖZET}

Hukukun temel işlevlerinden biri, hukuksal barış ve güvenliğin gerçekleştirilmesidir. $\mathrm{Bu}$ nedenle, her hukuk düzeni, bireyler arası ilişkilerde "haksız" olarak nitelediği davranışlar sonucu doğan zararların tazminine ilişkin çözümler üretmiştir. Bu durumu, Özel Hukuk alanındaki ilişkilerde kolayca gözlemlemek mümkündür. Aynı anlayışın gereği olarak, devlet organlarının da eylem ve işlemleri ile bireylere vermiş oldukları zararları karşılaması gerektiği düşünülebilir ise de; bu düşünce, çeşitli sebeplerle uzunca bir süre kabul edilmemiştir. Fakat günümüzde artık hiçbir uygar ülkede, kamusal gücün bireylere haksız olarak verdiği zararların yine devletçe üstlenilip karşılanması gereği, tartışma konusu yapılmamaktadır.

Çünkü gerek Fransa'da ve gerekse ülkemizde, öğretide olduğu kadar yargısal içtihatlarda da genel kabul gören yaklaşıma göre, İdarenin hukuki (mali)

\footnotetext{
* Dicle Üniversitesi Hukuk Fakültesi İdare Hukuku Anabilim Dalı Öğretim Üyesi.
} 
sorumluluğunun kabul edilmesi Hukuk Devletinin olmazsa olmaz gereklerinden biri olarak görülmektedir. Ancak, idarenin hukuki (mali) sorumluluğu ilkesi, Fransa'da olduğu gibi, ülkemizde de pozitif hukuk kurallarından önce ve onlardan ziyade yargısal içtihatlarla yaratılıp şekillendirildiğinden; sürekli bir değişim ve dönüşüm içinde olmuştur.

İdarenin sorumluluğu ile ilgili bu dinamik ve evrimsel özellik, kuşkusuz, kaçınılmaz olduğu kadar yararlıdır da. Zira ancak bu sayede, İdarenin her geçen gün artan ve karmaşık bir hal alan faaliyetlerinin yol açabileceği zararların tazmin edilebilme imkân ve koşulları ihtiyaçlara en uygun şekilde cevap verebilecek bir tarzda belirlenebilir. Ne var ki, bunun beraberinde getirebileceği birtakım sakıncalar da yok değil. Bunun en somut kanıtı ise, inceleme konumuzu teşkil eden; mahkemece hükmedilen manevi tazminata faiz de yürütülüp yürütülemeyeceği meselesidir. Gerçekten de, aşağıda ortaya koyacağımız gibi, hükmedilen manevi tazminata faiz yürütülüp yürütülmeyeceği sorununa ilișkin olarak Danıștay ve Askeri Yüksek İdare Mahkemesi kararları arasında bir birlik ve uyum bulunmadığı gibi, her bir Yüksek Mahkemenin kendi uygulaması da aynı birlik ve uyumu göstermekten uzaktır. Oysa özel hukuk alanında ve adli yarg1 yerlerinin uygulamasında, böyle bir sorunun yaşanmadığı görülmektedir. Nitekim gerek Yargıtay’ın ve gerekse doktrinin yaklaşımına bakıldığında, hükmedilen manevi tazminata faiz de yürütülmesi gerektiğinin tartışmasız bir şekilde kabul edildiği gözlenmektedir.

Hukuk düzeni bakımından arzu edilmeyecek bu sonucun bir an önce son bulmasında sayısız fayda vardır. Danıştay ve Askeri Yüksek İdare Mahkemesinin yeni kararlarında söz konusu duruma son verecek bir gelişmenin işaretleri görülmekte ise de, bu kararlara bakarak sorunun hal edilmiş olduğunu söylemek henüz erken görünmektedir.

Anahtar Kelimeler: Danıştay, Askeri Yüksek İdare Mahkemesi, Manevi Zarar, Tazminat, Faiz.

\section{ABSTRACT}

Establishing peace and security is one of the main objectives of law. Therefore, every legal system has provisions so as to prevent "unfair" behaviors among the individuals. It's very easy to detect this in context of relations of in the area civil law. As a result of same perception, one may think that state bodies are also responsible for their wrongful acts, however this had not been accepted until recently. But, in our time, none of civilized nation would allow unfair conducts of state actors. Even if such a conduct occurred states have to compensate damages caused.

Both in Turkey and France accepted approach is, in court decisions as well as doctrine, that the legal (and financial) responsibility of administration as one of the indispensable elements of the state of law. However, the principle of legal (and financial) responsibility is accepted in court decisions before positive law both in France and Turkey. This is why the principle is being evolved thorough the dictums 
of the courts. Thanks to this way of evolution of the principle it could easily adapted to the changing needs of the day. However it brings some inconveniences together. For instance, the problem of whether the courts could determine interests as well as compensation. There is no unanimous opinion between Council of State and High Military Administrative Court. Yet, there is no such problem in the administration of civil courts. In the application of The High Court of Appeals interest is paid as well as compensation without doubt.

The inconsistent practice between Council of State and High Military Administrative Court should end immediately for the sake of legal order. Despite signs for the solution in the latest decisions of the courts, it's early to say the problem has solved.

Keywords: Council of State, High Military Administrative Court, compensation, interest.

\section{GİRIŞ}

Hukukun, temel işlevlerinden olan hukuksal barış ve güvenliği gerçekleştirebilmesi için; her hukuk düzeni, bireyler arası ilişkilerde "haksız" olarak nitelediği davranışlar sonucu doğan zararların tazminine ilişkin çözümler üretmiştir ${ }^{1}$. Bunun kadar eskiye dayanmasa da, aynı anlayışın gereği olarak, devlet organlarının da eylem ve işlemleri ile bireylere vermiş oldukları zararları karşılaması gerektiği kabul edilmiştir. Bugün artık hiçbir uygar ülke, kamusal gücün bireylere haksız olarak verdiği zararların yine devletçe üstlenilip karşılanması gereğini, tartışma konusu yapmamaktadir ${ }^{2}$.

Günümüzde bu alanda yapılan tartışma, yalnızca söz konusu sorumluluğun temelinin (dayanağının) ne olduğu ile ilgilidir. Daha çok kuramsal bir özellik taşımakla birlikte, kamu gücünün sorumluluğu ile ilgili sağlam hukuksal temel ve gerekçelere dayanan çözümler üretilebilmesi için bu sorunun da açıklığa kavuşturulması gerekli ve yararlı görülebilir ise de $^{3}$; inceleme konumuzla doğrudan ilgili olmadığından ve çalışma konumuzun boyutlarını bir hayli aşacağından burada bu tartışmaya girişmeyeceğiz. Yalnızca şu kadarını belirtmekle yetinelim ki, bizim de taraftarı olduğumuz

${ }^{1}$ Cüneyt OZANSOY, Tarihsel ve Kuramsal Açıdan İdarenin Kusurdan Doğan Sorumluluğu, (Basılmamış Doktora Tezi, Ankara Üniversitesi Sosyal Bilimler Enstitüsü, Ankara, 1989 ) s. 22.

2 Lûtfi DURAN, Türkiye İdaresinin Sorumluluğu, TODAİE Yayını, Ankara, 1974, s. 11.

3 Gerçekten de DURAN'ın belirttiği gibi, "Sorumluluğun temeli, İdarenin verdiği zararı neden yükümlü olduğunu açıklamakla, bireylerin ve topluluklarının hangi hallerde kamu tüzel kişilerine karşı tazminat hakkı bulunduğunu belirler ve saptar.Başka bir deyişle, İdarenin genel tazmin borcuna karşlık, zarar görenlerin tazminat hakkının gerçekleşmesini sağlayan ana hukuki gerekçe, bunun kapsam ve sınırlarını ortaya çıkarabilir.”, bkz: DURAN, a.g.e., s. 12; aynı yönde değerlendirmeler için bkz: OZANSOY, a.g.t., s. 23 vd. 
doktrindeki hakim görüşe söz konusu sorumluluğun temeli Hukuk Devleti ilkesidir ${ }^{4}$. İşte, genel kabul gören yaklaşıma göre Hukuk Devletinin olmazsa olmaz gereklerinden biri olarak nitelendirilen idarenin hukuki (mali) sorumluluğu ilkesi, Fransa'da olduğu gibi, ülkemizde de pozitif hukuk kurallarından önce ve onlardan ziyade yargısal içtihatlarla yaratılıp şekillendirildiğinden; zaman içinde değişen koşullara göre farklı karakterler kazanması ve biçimlere bürünmesi de kaçınılmaz olmuştur.

İdarenin sorumluluğu ile ilgili bu dinamik ve evrimsel özellik, kuşkusuz, kaçınılmaz olduğu kadar yararlıdır da. Zira ancak bu sayede, İdarenin her geçen gün artan ve karmaşık bir hal alan faaliyetlerinin yol açabileceği zararların tazmin edilebilme imkân ve koşulları ihtiyaçlara en uygun şekilde cevap verebilecek bir tarzda belirlenebilir. Ne var ki, bunun beraberinde getirebileceği birtakım sakıncalar da yok değil. Bunun en somut kanıtı ise, inceleme konumuzu teşkil eden; mahkemece hükmedilen manevi tazminata faiz de yürütülüp yürütülemeyeceği meselesidir. Gerçekten de, aşağıda ortaya koyacağımız gibi, hükmedilen manevi tazminata faiz yürütülüp yürütülmeyeceği sorununa ilişkin olarak Danıştay ve Askeri Yüksek İdare Mahkemesi kararları arasında bir birlik ve uyum bulunmadığ 1 gibi, her bir Yüksek Mahkemenin kendi uygulaması da aynı birlik ve uyumu göstermekten uzaktır. Oysa özel hukuk alanında ve adli yarg1 yerlerinin uygulamasında, böyle bir sorunun yaşanmadığ 1 görülmektedir. Nitekim gerek Yargıtay'ın ve gerekse doktrinin yaklaşımına bakıldığında, hükmedilen manevi tazminata faiz de yürütülmesi gerektiğinin tartı̧̧masız bir şekilde kabul edildiği gözlenmektedir ${ }^{5}$.

Farklı yarg1 düzenleri içinde yer alan yargı yerlerinin farklı yönde içtihat oluşturmaları, hukukun devingen yönünün bir tezahürü olmak itibariyle, elbette ki olumludur. Ancak, durum bu yönüyle olumlu karşılanabilirse de, aynı hukuksal mesele hakkında birbirine zıt çözümlerin değişmeksizin uzun süre uygulamada kalmasının yol açabileceği birtakım olumsuzlukların olabileceği de inkâr edilemez. Çünkü bu durum, bir hukuk

4 Bkz: Tahsin Bekir BALTA, İdare Hukukuna Giris I, TODAİE Yayını, 1968/ 1970, s. 64; A.Şeref GÖZÜBÜYÜK/Turgut TAN, İdare Hukuku, Cilt: 1, Genel Esaslar, Güncelleştirilmiş 2. Bası, Turhan Kitabevi, Ankara, 2001, s. 658 vd; İsmet GİRİTL̇/ Pertev BİLGEN/ Tayfun AKGÜNER, İdare Hukuku, Der Yayınları, İstanbul,2001, s. 54 vd; Metin GÜNDAY, İdare Hukuku, 9. Bask1, İmaj Yayıncılık, Ankara 2004, s. 49 vd; OZANSOY, a.g.t.,s. 22 vd; Kemal GÖZLER, İdare Hukuku, Cilt II, Ekin Kitabevi, Bursa, 2003, s. 927. Buna karşılık, bazı yazarlar ise "imkân ve firsat eşitliği" (bkz: DURAN, a.g.e., s. 11 vd.) veya "sosyal hukuk devleti" (bkz: Yıldızhan YAYLA, İdare Hukuku I, Gözden Geçirilmis ve Genisletilmis İkinci Bası, Filiz Kitabevi, İstanbul, 1990, s. $134 \mathrm{vd})$ gibi ilkelerle açıklamaya çalışmıştır. İdarenin sorumluluğunun dayandığı temel hakkında daha geniş açıllamalar için bkz: DURAN, a.g.e., s. 11 vd.; OZANSOY, a.g.t., s. $22 \mathrm{vd}$.

5 Mehmet HELVACI, Borçlar ve Ticaret Kanunu Bakımından Para Borçlarında Faiz Kavramı, Beta, İstanbul, 2000, s. 110 vd. 
düzeninde bulunması gereken birlik ve uyuma ters düştüğünden, eşitsizlik ve adalesizliklere yol açması da kaçınılmaz olacaktır. Böyle bir olumsuzluğun ise, kişilerin Devlete ve onun kurduğu hukuk düzenine olan inancı ve güveni ne ölçüde sarsabileceğini tahmin ve tasavvur etmek zor olmasa gerektir.

İşte biz bu çalışmamızda, idari yargı yerlerinin, manevi tazminata faiz yürütülmesi hakkındaki uygulamalarını ortaya koymaya çalışacağız. Fakat faiz sorunu da, doğrudan manevi tazminatın kendisiyle ilgili olduğundan, kısaca da olsa, önce manevi tazminatın mahiyeti hakkında açıklamalarda bulunacağız ve daha sonra bu tazminata faiz yürütülmesi meselesi üzerinde duracağız.

\section{MANEVI TAZMINATIN NITTELİĞİ ve İSLEVİ}

Hemen belirtmek gerekir ki, İdare Hukukunda olduğu gibi, Özel Hukukta da gerek manevi tazminatın işlevi ve gerekse manevi zararın bizatihi kendisi uzunca bir süre tartışma konusu olmuştur ${ }^{6}$. Bu konuda, biri "objektif görüş" diğeri de "sübjektif görüş" olmak üzere başlıca iki görüş bulunmaktadir.

Objektif görüşe göre, maddi olmayan zarar denince bundan, en geniş anlamı ile kişilikte meydana gelmiş bir eksilme anlaşılır. Başka bir ifadeyle, bu görüş açısından manevi zarar; zarar görenin psikolojik varlığı üzerinde nasıl bir etki yaptığı göz önünde tutulmaksızın, bizatihi kişilikte veya kişisel varlıklarda meydana gelen objektif bir eksilmeyi ifade etmektedir. Zararın muhatabı olan kişinin duyması muhtemel acılar veya hoşnutsuzluk duyguları, manevi zararın varlık şartı değil, "ağırlaştırıcı" unsurları olarak nitelenmelidirler. Bunlar, ayrıca zarar görenin kişiliğinin hangi ağırlıkta bir ihlale hedef olduğunu ölçmeye yarayan önemli bir gösterge rolünü oynarlar ${ }^{7}$.

Kişilik haklarına yapılan saldırıların, mağdurun psikolojik varlığ üzerindeki etkisini ön planda tutan sübjektif görüşe göre ise; uğradığ1 tecavüz sonucu, fiziki veya manevi acilar duyan, ruhsal dengesi bozulan, yaşama sevincini kaybeden kişi, manevi bir zarara uğramış sayılır. Dolayısıyla, bu görüşe göre, manevi zarar (kişilikte objektif olarak gerçekleşen azalma + zarar görenin bu azalmanın bilincine varması ile çektiği acı ) formülü ile ifade edilebilir?'.

${ }^{6}$ P. ZEN-RUFFINEN, "İsviçre Sorumluluk Hukukunda Destekten Yoksun Kalma Tazminatı ve Manevi Tazminat Konusunda Yeni Gelişmeler", (Çeviren: Haluk BURCUOĞLU), İstanbul Barosu Dergisi, Cilt 59, Say1 4-5-6, 1985, s. 367; Necip KOCAYUSUFPAȘAOĞLU, "Kișilik Haklarını Koruyan Manevi Tazminat Davasına İlişskin Yeni Gelişmeler", Sorumluluk Hukukunda Yeni Gelişmeler I. Sempozyumu (Ankara, 21-22 Ekim 1977 ), Fakülteler Matbaası, İstanbul, 1980, s. 144 vd.

KOCAYUSUFPAŞAOĞLU, a.g.m., s. 144-145.

8 KOCAYUSUFPAŞAOĞLU, a.g.m., s. 145.

9 KOCAYUSUFPAŞAOĞLU, a.g.m., s. 147. 
Görüldüğü üzere, manevi zararın kişilik haklarına, örneğin yaşama ya da bedensel bütünlüğe objektif bir tecavüzü gerektirdiği konusunda fikir birliği bulunmakla birlikte, ikinci görüşü savunan yazarlar buna mağdurun tecavüzü hissedebilmesi gerektiği şeklinde sübjektif bir unsur da eklemişlerdir ${ }^{10}$. İşte, manevi zararın varlığından söz edebilmek için objektif unsura ek olarak bir de sübjektif unsurun gerçekleşmiş olması şartını arayan bu görüş sahiplerine göre; mağdur tecavüzü hissedebilecek olmalıdır, zira manevi zararın tazmini konusu zaten bu sübjektif acıdır. Diğer bir ifadeyle, maruz kaldığı tecavüzden acı duymayacak bir kimsenin manevi zarara uğramasından da söz edilemez ${ }^{11}$. Bu görüş doktrinde daha baskın olmakla birlikte $^{12}$, tüzel kişilere niçin manevi tazminat ödenmesi gerektiğini tatmin edici bir şekilde açıklayamaması ve temyiz kudretine sahip olmayanlara karşı haksız fiil işleyen kişileri cezasız bırakabilmesi yönlerinden eleştirilmiştir ${ }^{13}$.

Manevi zarar hakkındaki bu farklı görüşler, ister istemez manevi tazminatın işlevi hakkında da kendisini ortaya koymaktadır. Özel Hukuk alanında çok tartışılmış olan bu konuyu biraz basite indirgeyerek ifade etmek gerekirse; bu alanda, manevi tazminatın "cezalandırıcı" işlevi olduğu görüşü ile "giderici" (tatmin edici) işlevi olduğu şeklinde iki tezin çatıştığı söylenebilir ${ }^{14}$.

Failin kusurundan hareket eden ceza teorisi taraftarlarına göre, bir özel hukuk cezası olan manevi tazminat, cezalandırıcı ve önleyici niteliğe sahiptir. Zira haksız fiil failinden, manevi tazminat adı altında bir miktar para alınmak suretiyle zarar veren cezalandırılmaktadır. Burada, Devlet lehine değil, mağdur lehine bir cezalandırma yoluna gidilmektedir ${ }^{15}$.

Ceza teorisi öğretide büyük çoğunluk tarafından reddedilmekte ve manevi tazminatın özel hukuk nitelikli bir yaptırım olduğu

${ }^{10}$ ZEN-RUFFINEN, a.g.m., s. 367; Selahattin Sulhi TEKINAY/ Sermet AKMAN/ Haluk BURCUOĞLU/ Atilla ALTOP, Tekinay Borclar Hukuku Genel Hükümler, Yeniden Gözden Geçirilmiş ve Genişletilmiş Yedinci Bask1, Filiz Kitabevi, İstanbul, 1993, s. 668.

${ }^{11}$ Fikret EREN, Borçlar Hukuku Genel Hükümler, Tıpk1 7. Bask1, Beta, İstanbul, 2001, s. 777; ZEN-RUFFINEN, a.g.m., s. 367.

12 TEKINAY/ AKMAN/ BURCUOĞLU/ ALTOP, a.g.e., $\quad$ s. 665; KOCAYUSUFPAŞAOĞLU, a.g.m., s.145.

${ }^{13}$ EREN, a.g.e., s.778-779.

14 Ahmet KILIÇOĞLU, "Manevi Tazminatın Hukuksal Niteliği” Ankara Barosu Dergisi, 1984/ 1, s. 15; RUFFINEN, a.g.m., s. 369. Ancak bu konuda, uğranılan manevi zararı olabildiğince maddi zarara benzetmeye çalışan ve aynen veya nakden tazmin ve telafi edilmesi gerektiğini savunan "telafi görüşü" adında üçüncü bir görüş daha ileri sürüldüğg̈ gibi (Bkz: EREN, a.g.e., s. 778-779), manevi tazminatın hem cezalandırıc hem de tatmin edici olduğu yolunda bir görüss de ileri sürülmüştür. Bkz: Kemal Tahir GÜRSOY, "Manevi Zarar ve Tazmini” (Zarar), AÜHFD, Cumhuriyetin 50. Yılına Armağan, Cilt XXX, sayı 14, 1973, s. $10-11$.

${ }^{15}$ Ahmet KILIÇOĞLU, Borçlar Hukuku Genel Hükümler, 2. Bası, Turhan Kitabevi, Ankara, 2002, s. 287. 
savunulmaktadır ${ }^{16}$. Manevi tazminatın giderim yönüne ağırlık veren bu görüşe göre ise, zarar görene manevi tazminat adıyla bir para ödendiği takdirde, onda uğramış olduğu manevi zararı kısmen veya tamamen gidermeye yarayan bir tatmin duygusu yaratılmış olur ${ }^{17}$. Her ne kadar, mağdurun intikam duygusuyla da manevi tazminat davası açması mümkün ise de, hâkim manevi tazminata hükmederken bu davanın hangi saik ile açılmış olduğuyla ilgilenmediğinden, yine manevi tazminatın giderim karakterinin baskın geldiği kaydedilmektedir ${ }^{18}$.

Yukarıda da belirttiğimiz gibi, manevi tazminatın niteliği ve işlevi ile ilgili olarak yapılan tartışma ve ileri sürülen görüşler, esasen manevi zararın ne olduğu, neyi ifade ettiği ve kapsadığı konusundan çıktığ1 için zarar meselesi üzerinde kısaca da olsa durmanın yararlı olacağını düşünüyoruz.

${ }^{16}$ KILIÇOĞLU, a.g.e., s. 287; ZEN- RUFFINEN, a.g.m., s.369. Safa REİSOĞLU, Borçlar Hukuku Genel Hükümler, Değişiklik ve İlavelerle Onuncu Bask1, Beta, İstanbul, 1995, s. 176.

${ }_{17}^{17}$ EREN, a.g.e., s. 776; KILIÇOĞLU, a.g.m., 17.

${ }^{18}$ KILIÇOGLU, a.g.m., s. 20. Anayasa Mahkemesi de, Borçlar Kanununun 49. maddesinin Anayasanın (1961) 10. maddesine aykırılığı iddiasını incelerken manevi tazminatın niteliği ile ilgili olarak şu görüşlere yer ermiştir: “ Manevi zarar sorunu, zararın değerlendirilmesi ve giderilmesi yönlerinden özelliği ve büyük güçlükleri olan bir sorundur. Özellik ve güçlük, insanın manevi varlığına yapılan saldırıların tahriplerini ölçüye vurmaktaki imkânsızlıkta ve manevi kayıpların telafi kabul etmez niteliğindedir...Paranın manevi zararları karşılamak üzere kullanılabilmesi, hiçbir zaman manevi kaybı geri getirip yerine koyduğu yahut manevi varlığın bir bölümünün onunla mübadele edildiği anlamını taşımaz. Paranın bu alanda gördüğü iș, kișilik hakları ve yararları zedelenen kimsenin duyduğu ağır manevi acıyı bir dereceye kadar yumuşatıp yatıştırmaktan; bozulan manevi dengeyi onarıp düzeltmekten; bir teselli, bir avunma, bir ruhi tatmin aracı olmaktan ibarettir. Manevi varlıklarının hiçbir saldırıdan zarar görmeyeceğine inanan veya manevi kayıpları için her hangi bir tatmin yolunu gerekli görmeyen kimi insanlar bulunabilir. Ama bunların sayıs pek azdır. Büyük çoğunluk, genel olarak uğradığı haksız saldırının hesabını sorar ve zararlarının karşılanması yollarını arar. Bunu başarınca da bir tatmin edilmişlik duygusuna, hafifliğine, ferahlığına kavuşur...Hakarete uğrayan kimsenin, manevi tazminat olarak bir para isteminde bulunması, onun dokunulmaz, devredilmez, vazgeçilmez kişilik haklarını ve kişilik haysiyetini bir yana bıraktığını değil; tam tersine kişilik ve haysiyetine bağlılığının ve bunları koruma ve savunma azminin ifadesidir." Bkz: Anayasa Mahkemesinin 11.02.1969 tarih ve E. 1968/ 33, K. 1969/ 12 sayll kararı. Bkz: Anayasa Mahkemesi Kararlar Dergisi, Sayı 7, s. 242-243. Anayasaya aykırılık itirazında ise şu görüşlere yer verilmiştir: "Manevi tazminat olarak bir para istemek, böylece şeref ve haysiyetinin ve kişiliğinin tartısılmasına izin vermek, hele bu parayı varlığına karıstırmak davacının şerefinin, telafi edilememesine, lekelenmesine yol açar; vazgeçilmez kişilik haklarından feragat anlamını taşır ve yine davacı için insan haysiyeti ile bağdaşmayan ceza etkisini doğurur." İbid, s. 239-240.

Yargitay 4. Hukuk Dairesi ise,16.6.1977 tarih ve E. 1976/ 9690, K. 1977/ 7016 say1l kararında manevi tazminatın hukuksal niteliğiyle ilgili olarak şu görüşlere yer vermiștir: "Esasen manevi tazminat ne bir ceza, ne de gerçek anlamda bir tazminattır. 22.6.1966 günlü ve 7/7 sayılı İçtihadı Birleştirme Kararının gerekçesinde belirtildiği gibi, ceza değildir; çünkü davacının yararı düșünülmeksizin sorumlu olana hukukun ihlalinden dolayı yapılan bir kötülük değildir. Mamelek hukukuna ilişkin bir zararın karşılanmasını amaç edinmediği için de gerçek anlamda bir tazminat sayılmaz. Manevi tazminat yukarıda da belirtildiği veçhile mağdurda veya zarara uğrayanda bir huzur hissi, bir tatmin duygusu doğurmalıdır. Manevi tazminatta temel olan ana düşünce budur.” Bkz: Yargitay Kararlar Dergisi, 1978, Cilt 4, Say1 6, s. 915. 
Manevi zarar kişinin haysiyetine, vücut tamlığına veya yakınlarına yapılan saldırılar nedeniyle duyduğu bedensel ve ruhsal acı ve üzüntülerdir ${ }^{19}$. $\mathrm{Bu}$ gibi hallerde, kişiye miktar olarak ölçülemeyen maddi veya manevi bir acı verilmesi (ölüm halinde ölenin yakınlarının manevi acı duymaları, cismani zarar halinde yaralanan kimsenin maddi bir acı duyması gibi) veya kişinin toplum içinde küçük düşürülmesi (kişilik haklarına saldırı halinde) söz konusudur ${ }^{20}$.

Fakat bu tür zararların, genel anlamda zarar kavramıla kolayca örtüşmediği açıktır. Zira geniş anlamda bir şahsın mal bütünlüğünde eksilme veyahut mümkün iken mal bütünlüğünün fazlalaşmamış olması halinde zarardan bahsedilir ${ }^{21}$. Diğer bir ifadeyle, gerçek anlamda zarar, mal varlığında meydana gelen bir azalmadan ibarettir. O halde, zarara uğradığını iddia eden bir kimsenin mal varlığında böyle bir azalma meydana gelmiş olmalıdır. Ne var ki, bazen hukuka aykırı eylem veya işlemden bu mahiyette olmamakla birlikte, yine de muhatabı üzerinde olumsuz sonuçlar yaratan bir durum meydana gelebilir. Örneğin duyulan üzüntü, ac1 ve 1stırap hallerinde durum böyledir. $\mathrm{Bu}$ gibi hallerde, kişi haksız eylemden bir üzüntü ve acı duyduğu halde, malvarlığında bir azalma meydana gelmiş değildir ${ }^{22}$. İște, bu nitelikte ve insanın ruhsal âleminde cereyan eden ve hukuka aykırı davranışın sonucu olan bu durumları, teknik anlamda zarar olarak nitelendirmek mümkün değildir ${ }^{23}$. Ancak, hukuk düzeni bu gibi durumlara da ilgisiz yahut seyirci kalmamış, kişiler hakkında etkili olan söz konusu olumsuzlukları önlemek ve sonuçlarını gidermek için bir takım çareler geliştirmiştir.

${ }^{19}$ GÜNDAY, a.g.e., s. 345; GÖZÜBÜYÜK/TAN, a.g.e., s. 715.

20 GÜRSOY, Sorumluluk, s. 112. KILICOĞLU, a.g.m., s. 21.

${ }^{21}$ Reha T. ALPASLAN, "Manevi Tazminat Konusuna Genel Bakış", Adalet Dergisi, Cilt 58, 1967, s. 607.

${ }^{22}$ Kemal Tahir GÜRSOY, "İdarenin Sorumluluğuna İlișkin İlkelerde Son Gelişmeler ve İsviçre Hukukunda İdarenin Hukuki Sorumluluğunun Ana Hatları" (Sorumluluk), Sorumluluk Hukukunda Yeni Gelişmeler III. Sempozyumu, Ankara, 12-13 Mayıs, 1980, IUUHFY, İstanbul, 1980, s. 112

${ }^{23}$ Nitekim İsviçre Borçlar Kanununda, bu gibi durumlar "unbill”" terimi ile ifade edilmiş ve bunun karşıllı̆̆ında sorumlunun saldırıya uğrayan lehine yapacağı edaya da tazminat değil "genugtuung" denilmiştir. Bkz: GÜRSOY, Sorumluluk, s. 113. Böylece, "maddi olmayan zararın tazmini" ile "mağdura yapılan haksızlık sonucu zedelenen hak ve adalet duygusunun tatmin edilmesi" (genugtuung) arasinda bir ayrim yapılmakta ve manevi anlamda dahi "zarar" fikrine yabancı olan ikinci ihtimalin, uygulamada böyle bir ayrım gerçekleştirmenin son derece güç olmasına rağmen, birinci ile karıştırılmaması gerektiğ ileri sürülmektedir. Bkz: KOCAYUSUFPAŞAOGLU, a.g.m., s. 145, dipnot 9. 
Manevi zarar açısından çeşitli tasnifler yapılabilirse $\mathrm{de}^{24}$, yaratacağ etkileri bakımından başlıca iki tür manevi zarardan söz edilebilir: Salt manevi zararlar ve maddi etkileri de olan manevi zararlar. Örneğin, kendisine haksız yere suç isnat olunan ve bu yüzden işini kaybeden kişinin uğradığ1 zarar hem manevi ve hem de -işini kaybetmiş olması dolayısıylamaddidir ${ }^{25}$. Bunun gibi, kişinin beden bütünlüğüne yapılan saldırı nedeniyle çalışma ve kazanma gücünde bir azalma olması halinde de durum aynıdır ${ }^{26}$. Yahut kişinin şöhretine bir saldırı olması halinde de hem maddi ve hem de manevi bir zararın ortaya çıkması mümkündür ${ }^{27}$. Dolayısıyla, manevi zararlar1, salt manevi zararlar ve maddi etkileri de olan manevi zararlar şeklinde iki gruba ayırmak mümkündür ${ }^{28}$.

Kuşkusuz, maddi etkileri de olan manevi zararların tazmini, salt manevi zararlara göre nispeten daha kolaydır. Nitekim bu nedenledir ki, Fransız Danıştay'1 doktrindeki eleştirilere rağmen ${ }^{29}$ uzunca bir süre, salt manevi nitelikte olan zararların tazmini taleplerini reddetmiștir. Bu bağlamda, maruz kalınan fiziksel ve manevi acılar nedeniyle talep edilen manevi tazminat taleplerini, "fiziksel acılar parayla ölçülemez", "gözyaşları para etmez" gibi

${ }^{24}$ Örneğin, "beden tamlığının ihlalinden doğan acı ve üzüntüler”, “ölüm dolayısıyla ölene yakından bağlı olan kişilerin duydukları acı ve üzüntüler" ve "genellikle kişilik haklarının ihlalinden doğan ac1 ve üzüntüler" şeklinde ayrımlar yapıldığ 1 gibi (Bkz: TEKİNAY) AKMAN/ BURCUOGLU/ ALTOP, a.g.e., s. 656), "san, seref ve kișilik haklarına verilen zararlar", "estetik zararlar", "fiziksel acılar" ve "manevi acılar" ş̧eklinde bir tasnife de yapılmaktadır. Bkz: GÖZLER, a.g.e., s. 1192 vd. Fransız Hukukunda ise daha kapsamlı tasniflerin yapıldığı görülmektedir Buna göre, manevi zararlar;

1) Sosyal kişilik değerleri varlığına ilişkin zararlar ( l'atteinte à la partie sociale du patrimoine sociale)

- Kişinin onuruna ilişkin zararlar

- Kişinin eseri üzerindeki manevi hakkına ilișkin zararlar

2) Moral düşünce ve değerlere ilișkin zararlar (l'atteinte aux idées morales )

- Duygu, inanç ve kanaatlere iliş̧kin zararlar

3) Yaşam koşullarındaki bozulmalardan doğan zararlar ( les troubles dans les conditions d'existence)

4) Beden bütünlüğüne ilişkin zararlar ( l'atteinte à l'intégrité corporelle )

- Cismani zararlar

- Fiziki acilar

- Estetik zararlar

5) Manevi ac1lara iliskin zararlar ( l'atteinte aux sentiments d'affection )

Olmak üzere, beşli bir ayrıma tabi tutulmuştur. Bkz: René CHAPUS, Responsabilité Publique et Responsabilité Privé ( Responsabilité ), LGDJ, Paris, 1957, s. 409-426; René CHAPUS, Droit Administratif Général, Tome I ( Droit Administratif ), 11. édition, Montchrestien, Paris, 1997, s. 1113.

${ }^{25}$ Aytekin ATAAY, Borçlar Hukukunun Genel Teorisi, Birinci Yarım, Üçüncü Bası, Fakülteler Matbaası, İstanbul, 1981, s. 89-90.

${ }_{26}^{26}$ GÜNDAY, a.g.e., s. 345; GÖZLER, a.g.e., s. 1194.

27 GÖZLER, a.g.e., s. 1193.

${ }^{28}$ GÖZÜBÜYUK/ TAN, a.g.e., s. 715.

${ }^{29}$ Fransız Danıștay'ının bu konudaki içtihadının tarihsel seyri üzerinde genis ve ayrıntılı açılamalar içeren iki kaynak olarak bkz: Maryse DEGUERGUE, Jurisprudence Et Doctrine Dans L'Élaboration Du Droit De La Responsabilité Administrative, LGDJ, Paris, 1994, s. 426 vd; CHAPUS, Responsabilité, s. 408 vd. 
gerekçelerle reddetmiştir ${ }^{30}$. Hatta bu şekildeki manevi tazminat talepleri, manevi acı ve üzüntülerden menfaat sağlama yahut onları paraya tahvil etme olarak değerlendirilerek, gayrı ahlaki dahi bulunmuştur ${ }^{31}$. Uzunca bir süre bu içtihadını sürdüren Fransız Danıştay'1, bu tutumundan ancak 24 Kasım 1961 tarihli "Letisserand" kararıyla vazgeçmiştir ${ }^{32}$. Fransız Danıştayı'nın bu şekilde bir içtihat değişikliğine gitmesini sağlayan faktör ise, doktrindeki eleştirilerden ziyade Fransız Yargıtayı'nın söz konusu zararları 1800'lü yılların başından beri tazmin ede gelmesi olmuştur ${ }^{33}$.

Manevi zararın ve onun karşıllı̆ını teşkil edebilecek manevi tazminatın niteliği göz önünde bulundurulduğunda, Fransız Danıştayı'nın bu tür zararları tazmin etmeyi reddetmesini anlamak zor değildir. Şöyle ki; "şan, şeref ve kişilik hakları"na verilen zararlar ile "estetik zararlar" gibi, kişinin malvarlığ 1 üzerinde dolaylı da olsa etkisi veya yansıması olan manevi zararlar bir yana bırakılırsa ${ }^{34}$, fiziki ve manevi acılar nedeniyle uğranılan zararın ölçülmesindeki ve parayla takdir edilip giderilmesindeki güçlük açıktır. Zira her şeyden önce, kişinin böyle bir zarara uğradığını kanıtlamasında güçlük vardır. Öte yandan, davacı bunu kanıtlama yükümlülüğünden bağışık tutulsa bile; örneğin, dış görünüş karineleriyle yahut hayat tecrübelerinden çıkarılan sonuçlarla yetinilse dahi, bu defa da maruz kalınan zararın miktarını tespit etmek imkânsızdır. Öyle ki, bir müellifin haklı olarak belirttiği gibi" "genel olarak manevi zararın kanıtlanması imkânsızdır. Adli mahkemeler kanıt getirme yükümlülüğünden davacıları bağışık tutarak da güçlüğün üstesinden gelemediler. Manevi zararı kanıtlamak için yapılacak her araştırma boşuna ve zahmetli olacaktır. Ve eğer yargıç tarafından harici tezahürler nazara alınırsa, nasıl bir komedinin gözler önünde cereyan edeceğini tahmin etmek zor değildir."

${ }^{30}$ Jean RIVERO/ Jean WALINE, Droit Administratif, 20. édition, Dalloz, Paris, 2004, s. 402;GÖZLER: a.g.e., s. 1192 vd; E. Ethem ATAY/Hasan ODABASI/Hasan Tahsin GÖKCAN: Teori ve Yargı Kararları Işığında İdarenin Sorumluluğu ve Tazminat Davaları, Seçkin, Ankara, 2003, s. 160 vd.

31 CHAPUS, Droit Administratif, s. 1114

${ }^{32}$ Karar için bkz: Jean-François LACHAUME, Les Grandes Decision De La Jurisprudence, Onziéme édition, Puf, Paris, 1997, s. 540 vd. Halbuki, Fransiz Yargitay Genel Kurulu, 25 Haziran 1833 sayılı kararıly manevi ve fiziki acı ve üzüntülerin de tazmin edilmesi gerektiğine hükmetmiş ve o tarihten beri de bu içtihadını sürdüre gelmiştir; bkz: DEGUERGUE, a.g.e., s. 426; GÖZLER, a.g.e., s. 1196.

${ }^{33}$ DEGUERGUE, a.g.e., s. $425 \mathrm{vd}$.

${ }^{34}$ Fransız Danıştay'ı bu tür zararları nispeten daha eski bir tarihten, 1930'lu yılların başından itibaren tazmin etmeye başlamıștır; bkz: DEGUERGUE, a.g.e., s. 426 vd; CHAPUS, Responsabilité, s. 412 vd ; Gilles DARCY, La Responsabilité De l'Administration, Dalloz, Paris, 1996, s. 122; Christophe GUETTIER, La Responsabilité Administrative, LGDJ, Paris, 1996, s. 135; Isabelle POIROT-MAZERES, La Notion De Préjudice En Droit Administratif Français, Revue Du Droite Public, 1997, s. 525 vd.; GÖZLER, a.g.e., s. $1193 \mathrm{vd}$; ATAY/ODABAŞI/GÖKCAN, a.g.e., s. $160 \mathrm{vd}$.

${ }^{35}$ M. Georges MORANGE, Le Préjudice Moral Devant Les Tibunaux Administratifs, Dalloz, 1948, s. 105 (Aktaran, Turgut CANDAN, Fransa ve İngiltere'de İdarenin Sorumluluğu, Danıştay Başkanlığı Yayını, Ankara, 1984, s. 65). 
Gerçekten de, manevi zararın maddi zarar gibi "gerçek" bir saptamaya konu olamayacağ 1 açıktır. Çünkü manevi zararın bir ölçüde somutlaşması demek ola acı, 1stırap, eza, sıkıntı, ruhsal çöküntü vb. hallerin ölçümlenmesi olanaksızdır ${ }^{36}$. O halde, manevi tazminat neye karşılık olarak verilmektedir ve tutarı nasıl belirlenmektedir? $\mathrm{Bu}$ soruya şöyle cevap verilmektedir: "Manevi tazminat gerçekte bir tatmin aracı değil, doyurma (tatmin) aracıdır. Manevi değerlerinde bir eksilme meydana gelen, duyduğu acı (elem, 1stırap), üzüntü ve sarsıntı nedeniyle yaşama zevki azalan kişiye manevi tazminat adı ile bir miktar para verilerek, onun bu yoldan doyurulması (tatmin edilmesi) sağlanır. Buna 'acı parası' da denilmektedir"37. "Manevi zarar için yapılan ödemede amaç, maruz kalınan olay veya durum dolayısıyla hayat şartlarında kişilerin karşılaştıkları karmaşanın belli bir ölçüde de olsa giderilmesi, normale dönme için yardımcı olunmasıdır. Ödenen tazminat, tabiri caizse, zarara uğrayan kimsenin belleğinden yaşanılan olayların etki ve izlerini silmek veya yoğunluğunun azaltılmasını sağlamaktır. Şu bir gerçektir ki, ödenecek tazminat miktarı ne olursa olsun, hiçbir zaman uğranılan zararın karşılığı olamaz. Çünkü zamanı ters çevirip zarar verici olayın hiç olmamış gibi, eski durum ve şartların yaratılması mümkün değildir. Manevi tazminata hükmedilmesi ile zararın mağdurunun manevi alanda uğramış olduğu yıkıntı, elem ve istırap belli bir ölçüde tatmin edilemeye çalış1lır"38. "Böylece, manevi tazminatta, 'gerçek zarar', halen gerçekleşmiş ve ilerde devam edecek manevi zararı içermekle beraber, hem zararın miktarı, hem de rakam olarak tazminata çevrilemesi bakımından kesinlik arz edemeyen, ölçülemeyen, somutlaştırılamayan, zararın tümünü kapsayamayacak olan bir nitelik taşımaktadır. Zaten bu yüzden hem zarar hem de manevi tazminat miktarı 'takdiren' hesaplanıp, 'kısmen telâfi, tahfif, tatmin' etmek üzere hükmolunmaktadır" $"$.

Manevi tazminatın niteliği ve işlevi ile ilgili olarak İdare Hukuku öğretisinde dile getirilen bu görüşlerden çıkardığımız diğer bir sonuç da, bu konuda Özel Hukukta da doktrinin büyük çoğunluğu tarafindan paylaşılan giderim (tatmin) görüşünün benimsendiğidir. Danıştay kararlarında da, esas itibariyle bu görüş benimsenmekle beraber, “ceza görüşü̈nün benimsediği

${ }^{36}$ Yahya K. ZABUNOĞLU, İdari Yargı Hukuku Dersleri, (Ankara, 1980-1981, Teksir), s. 275; K. Eren GÖNEN, “İdari Yargıda Manevi Tazminat Meselesi”, Danıştay Dergisi, Sayı 108, s. $23 \mathrm{vd}$.

37 Yüksel ESİN, Danıştay'da Açılacak Tazminat Davaları, İkinci Kitap, Esas, Ankara, 1973, s. 450.

${ }^{38}$ ATAY/ODABAȘI/GÖKCAN, a.g.e., s. 159-160.

${ }^{39}$ Sait GÜRAN, "Türk İdare Hukukunda Tazminat Miktarının Saptanması", Sorumluluk Hukukunda Yeni Gelişmeler III. Sempozyumu, Ankara, 12-13 Mayıs 1980, IÜHFY, İstanbul, 1980, s. 157. Fransız Hukukunda da aynı yönde değerlendirmeler yapılmakta ve niteliği ne olursa olsun manevi zarar karșllığı olarak hükmedilecek tazminatın "götürü" veya "takdiri”" bir meblağ olarak belirlenmesinin zorunlu olduğu belirtilmektedir. Bkz: Michel PAILLET, La Responsabilité Administrative, Dalloz, Paris, 1996, s. 260 vd. 
izlenimini uyandıran kararlara da rastlamak mümkündür ${ }^{40}$. Buna karşı1ık, Askeri Yüksek İdare Mahkemesinin ise tatmin görüşünden ziyade, Özel Hukuk alanında da bazı yazarlarca benimsenen "telafi görüşü"ne daha yakın durduğu söylenebilir ${ }^{41}$.

Sonuç olarak, manevi tazminatın niteliği ve işlevi hakkında Özel Hukuk alanındaki yasal düzenlemeler (B.K., M.K.) ile ileri sürülen görüş ve uygulamaların İdare Hukuku öğretisi ve uygulamasını etkilediğini söyleyebiliriz ${ }^{42}$. Ancak bu etkilenme, daha dar ve sinırlı bir sorumluluk ve tazmin anlayışının kabulüyle sonuçlanmıştı ${ }^{43}$. Bu durum, aşağıda ortaya koyacağımız gibi, hem hükmedilen tazminat tutarı ve hem de hükmedilen tazminata faiz yürütülmemesi bakımından kendisini göstermektedir.

\section{DANIŞTAY'IN UYGULAMASI}

Danıştay'ın konuya ilişkin içtihadına bakıldığında, yakın zamana kadar manevi tazminata faiz yürütülmesi taleplerini reddettiği görülmektedir. Faiz ile manevi tazminatın niteliği arasında bir bağ kuran Danıştay, bunun nedenini şöyle ifade etmektedir:

“...Manevi tazminata faiz yürütülmemesinin nedenini ortaya koyabilmek için manevi tazminatın hukuki niteliğinin açılanması gerekmektedir.

Kişinin manevi varlığının ihlalini ölçüye vurmak ve manevi kayıplarını tümüyle gidermek olanaksızdır. Manevi zarar söz konusu olduğunda bunun değişik biçimlerde karşılanması mümkündür. Ancak, pratik sonuçları ve tarafların istekleri göz önünde tutulunca uygulamada geniş oranda, manevi

40 Örneğin Danıştay 10. Dairesinin 20.04.1989 tarih ve E. 1988/1042, K. 1989/857 sayıl1 kararı, Danıștay Dergisi, Sayı 76-77, s. 783; başka bir kararında da azlık oyunda şu görüs dile getirilmiştir: "Bir tazmin aracı değil bir tatmin aracı olmakla birlikte manevi tazminatın olayın ağırlığına, idarenin olaydaki kusuruna göre ve bu tazminat türünün cezai niteliği de dikkate alınmak suretiyle saptanması gerektiği açıktır.” bkz: Danıştay 10. Dairesinin 12.07.1995 tarih ve E. 1994/7359, K. 1995/3559 sayılı kararı, Danıştay Dergisi, Say1 91, s. 1115-1116. Doktrinde de, GÜRAN, manevi tazminata, manevi zararı hafifletme, karş1lama 'sembolik' işlevinin yanında, özellikle kusurun belirginleșip ağırlaştığı davalarda -ajana rücû koşuluyla da- İdare'yi bir nevi 'cezalandırma' işlevi de kazandırılmasının uygun olacağını belirtmektedir. Bkz: GÜRAN, a.g.m., s. 167-168.

${ }^{41}$ GÖNEN, a.g.m., s. 25.

42 Ancak, Danıştay manevi tazminat taleplerinin Borçlar Kanunu hükümlerine dayanarak tazmin edilmesini kabul etmemektedir. “... Buna karş1lk idare hukukunda manevi tazminatın dayanağını yargı içtihatları oluşturduğundan görevine son verilmesi işlemi nedeniyle davacının uğradığını öne sürdüğü manevi zarara karşılık olarak mahkemenin Borçlar Kanunu hükümlerine dayanarak manevi tazminata hükmetmesi hukuken doğru olmadığı gibi ..." (Danıştay 5. Dairesinin 5.12.1991 tarih ve E. 1991/3619, K. 1991/2346 sayı1 1 kararı, Danıstay Dergisi, Sayı 84-85, s. 347).

${ }^{43}$ Tekin AKILLIOĞLU, "Gözlemler: Yönetsel Yargıda Manevi Giderim ve Bilgi Hukuku Gelişmesi”, Amme İdaresi Dergisi, Cilt 22, Say1 2, Ankara, 1989, s. 107; ESIN, a.g.e., s. 450-451; ZABUNOĞLU, a.g.e., s. 275-276. 
zararı karşılamak üzere para olarak karşı tarafın belli bir ödemede bulunması öngörülmektedir.

Maddi tazminat, bir kimsenin malvarlığında meydana gelen eksilmeyi karşılamaktadır. Bu karşılamanın zaman süreci içinde gecikmesi de ayrıca hükmedilecek tazminata faiz yürütülmesini gerekli kılmaktadır. Manevi tazminatın bu niteliği göz önünde tutulunca maddi tazminat gibi bunu da aynı ölçüler içinde değerlendirmeye tâbi tutmakta, davacının malvarlığında bir eksilme varmışçasına manevi tazminata faiz yürütülmemesinde isabet olacağı açıktır..."44.

“...Belli bir zararın karşılığı olmayıp, olay nedeniyle duyulan üzüntünün kısmen giderilmesi amacını taşıyan manevi tazminata, özelliği nedeniyle faiz yürütülmesine olanak yoktur..."45.

“...Manevi tazminat patrimuanda meydana gelen bir eksilmeyi karşılamaya yönelik bir tazmin aracı değil, manevi bir tatmin aracıdır. Diğer yandan faiz ise, belli bir paranın getirisidir. Başka türlü giderim yollarının bulunmaması veya yetersiz kalması nedeniyle manevi tazminatın değerinin parasal olarak belirlenmesi, manevi tazminata faiz yürütülmesini haklı kılacak bir neden değildir. Buna göre, belli bir zarar karşılığı olmayıp, olay nedeniyle duyulan üzüntünün kısmen giderilmesi amacını taşıyan manevi tazminata, özelliği nedeniyle faiz yürütülmesine olanak yoktur..."46.

"...Manevi tazminat patrimuanda meydana gelen bir eksilmeyi karş1lamaya yönelik bir tazmin aracı olmayıp manevi tatmin aracı olduğu, zenginleşmeye yol açmayacak miktarda fakat idarenin olaydaki kusurunun ağırlığını ifade edecek ve ilgilinin duyduğu acı ve üzüntüyü kısmen de olsa giderecek ölçüde saptanması gerektiği, manevi tazminatın bu niteliği itibariyle faiz istenilmesine olanak bulunmadığ $1 . . .47$.

Aktarılan kararlarından anlaşıldığına göre, Danıştay'ın manevi tazminata faiz yürütmemesinin nedeni, zararı değerlendirme zamanıyla ilgili

${ }^{44}$ Danıştay 10. Dairesinin 23.06.1982 tarih ve E. 1982/235, K. 1982/1765 sayılı kararı, (karar yayımlanmamıştır), Tuncay ARMAĞAN, İdarenin Sorumluluğu ve Tam Yargı Davaları, Seçkin Yayınevi, Ankara, 1997, s. 310.

45 Danıştay 10. Dairesinin 16.01.1985 tarih ve E. 1982/2908, K. 1985/26 sayılı kararı, Danıștay Dergisi, Sayı: 60-61, s. 462.

${ }^{46}$ Danıştay 10. Dairesinin 05.02.1998 tarih ve E. 1996/3984, K. 1998/545 say1lı kararı, ATAY/ODABASSI/GÖKCAN, a.g.e., s. 160, dipnot 33.

${ }^{47}$ Danıştay 10. Dairesinin 13.10.1999 tarih ve E. 1997/2216, K. 1999/4812 say1lı kararı, Yakup BAL/Yahya ŞAHIN/Mustafa KARABULUT, Danıştay 10. Dairesinin Tazminat Davalarına İlișkin Seçilmiș Kararları, Seçkin Yayınları, Ankara, 2003, s. 151; aynı yönde diğer kararlar için bkz: Danıştay 10. Dairesinin 24.11.1982 tarih ve E. 1982/469, K. 1982/2357 sayılı kararı, Danıştay Dergisi, Sayı: 46-47, s. 420; Danıştay 10. Dairesinin 01.05.1984 tarih ve E. 1984/1041, K. 1984/910 sayılı kararı, Danıstay Dergisi, Sayı: 56 57, s. 401; Danıştay 10. Dairesinin 25.05.1988 tarih ve E. 1987/2113, K. 1988/906 say1lı kararı, Danıştay Dergisi, Sayı: 72-73, s. 671. 
olmayıp, manevi zararın kendisiyle ilgilidir. Bu nokta önemlidir. Zira aşağıda belirteceğimiz gibi, Askeri Yüksek İdare Mahkemesi de bir dönem faiz taleplerini reddetmiş; fakat bunu, zararın hükmün verildiği tarih itibariyle değerlendirilmiş olduğu gerekçesine dayandırmıştır. Dolayısıyla, bu gerekçeye göre, esasında faizin işlevi de karşılanmış olmaktadır. Oysa Danıştay'ın ret gerekçesi bütünüyle manevi zarar ve onun karşılığını teşkil eden manevi tazminatın niteliğiyle ilişkilendirilmiştir ve bizce doğru olmayan bir sonuca ulaşılmıştır. Çünkü Danıştay'ın gerekçeleri, idari yargı yerlerinde uygulanan yasal ve içtihadi birtakım yargılama hukuku prensipleri nedeniyle kaçınılmaz olarak bazı hak kayıplarına yol açacaktır.

Şöyle ki; manevi tazminat talebinde bulunan davacı, bunun miktarını belirlerken haklı olarak, hükmün verileceği tarihe göre değil, davayı açacağ 1 tarihe göre hareket edecektir. Zira hükmün ne zaman verileceği belli değildir. Şu halde, davacı talep edeceği manevi tazminat tutarını belirlerken iki hususu gözetmek zorundadır. Birincisi; talebi hüküm tarihi esas alınarak değerlendirileceğinden, aradan geçen zaman zarfında paranın değerinde meydana gelebilecek kayıpları da göz önünde bulundurmak suretiyle bir meblağ tespit etmek zorundadır. Asi takdirde, mahkeme taleple bağlı olduğundan ve talepten fazlasına hükmedemeyeceğinden, davacının davanın başında yapacağı yanlışlık ileride hak kaybına yol açabilecektir ${ }^{48}$. Diğer bir ifadeyle, mahkeme, davacının talep ettiğinden daha fazla bir miktarda manevi tazminata hükmetmeyi düşünse bile, taleple bağlılık kuralı buna izin vermeyecektir. Diğer taraftan, adli yargıda olduğu gibi fazlaya ilişkin hakların saklı tutulması suretiyle dava açılması (=kısmi dava), yahut davacının 1slahı yoluyla talebini arttırmas ${ }^{49}$ veya asıl dava sonuçlandıktan

\footnotetext{
${ }^{48}$ İdari Yargılama Usulü Kanununda açıkça yer almamakla birlikte, uyuşmazlık konusu miktarın dava dilekçesinde belirtilmesi gerektiği kuralından (m.3/d) hareketle, istemle bağlılık, yargılama usulünün genel prensiplerinden biri olarak kabul edilip uygulanmaktadır. Söz konusu uygulamanın eleştirisi için bkz: Mehmet ÜNLÜÇAY, "Idarenin Tazmin Borcu ve Enflasyon Olgusu", Danıştay Dergisi, Say1 94, s. 7 vd.

49 "Islahın konusu, tarafların yapmış olduğu usul işlemlerinin düzeltilmesidir. Resmi Gazetenin 04 Kasım 2000 tarihli nüshasında Yayımlanan Anayasa Mahkemesi kararı incelendiğinde, söz konusu H.U.M.K.'nun 87 nci maddesindeki kuralın, davacıları ikinci kez dava açmaya zorlaması nedeniyle hak arama özgürlüğünü kısıtladığından bahisle iptaline karar verdiği anlaşılmaktadır. Adli yargıda zamanaşımı süreleri dikkate alındığında bu süreler içerisinde ava devam ederken bilirkişi raporları sonrasında ortaya çıkan tazminat farkının ikinci bir ek dava ile istenebileceği açıktır. Oysa ki 1602 sayılı Kanun gereğince Askeri Yüksek İdare Mahkemesinde açılan davalarda bir yıllık ve idari başvurudan sonra altmışar günlük dava açma süreleri, işlemektedir. Bu süreler geçirildikten sonra müddeabihin miktarının değiştirilemeyeceği 1602 sayılı AYİM Kanununun 46/4 ncü maddesinin ıslah talebinin yasal süreler geçirildikten sonra yapıldığı, ilk dava dilekçesinde fazlaya ait istemin saklı tutulmasının da durumda bir değișiklik yaratmayacağı sonuç ve kanaatine varılarak 1slah talebi kabul edilmemiştir." (AYIM 2. Dairesinin 16.6.2004 tarih ve E. 2000/494, K. 2004/571 sayılı kararı, AYIMMD, Say1 20, Kitap: 2, s. 1101). Aynı yönde Baska kararlar icin bkz: AYİM 2. Dairesinin 27.11.2002 tarih ve E. 2002/565, K. 2002/911 sayıl1 kararı, AYİMD, Say1 18, Kitap:2, s. 872-875; AYİM 2. Dairesinin 29.1.2003 tarih ve E. 1995/850, K. 2003/101 say1l karar1, AYİMD, Say1 18, Kitap:2, s. 810-813.
} 
sonra faiz için ek dava açılması gibi olanakların idari yargıda kabul görmemesi, davaciyı ister istemez olabildiğince mahkemece kabul edilebilecek bir tutar belirlemeye zorlamaktadır ${ }^{50}$. İkincisi; davacı, talebinin reddedilen kısmı üzerinden davalı idareye vekâlet ücreti ödemek zorunda kalacağından, bu defa da mahkemenin kabul edebileceğinden fazlasını istememek zorundadır. Kısacası, davacı talebini belirlerken mahkemenin kabul edebileceğinden ne az ne de çok istemelidir. Ancak, söz konusu talep hükmün verileceği sırada değerlendirilecekse ve bunun için de davanın açıldığ 1 tarihin üzerinden yılların geçmesi gerektiği göz önünde bulundurulursa, davacının kendi aleyhine sonuç doğurmayacak bir meblağı tespit edebilmesindeki güçlük açıktır" .

Örneğin somut bir örnek olarak, Gözler'in uygulamadan verdiği şu olay1 ele alalım: Danıştay 10. Dairesinin 18 Şubat 1998 tarih ve E. 1996/ 4835, K. 1998/ 703 sayılı kararına konu teşkil eden olayda, 13 Ocak 1992 tarihinde meydana gelen bir kaza sonucu beş yaşındaki bir kız çocuğunun vücudu kısmen yanmış ve çalışma gücünde de \% 13 oranında kayıp meydana gelmiştir. Bu kız çocuğu, 25 milyon lira maddi ve 15 milyon lira da manevi olmak üzere toplam kırk milyon liralık tazminat davası açmıştır. Mahkeme, davacının talebini beş milyon eksiğiyle, yani 35 milyon Türk Lirası olarak kabul etmiştir. Ne var ki, olay günü itibariyle kırk milyon lira 7400 Amerikan Dolarına tekabül ediyor iken, idare mahkemesinin karar tarihi olan 9 Kasım 1995 tarihinde 35 milyon Türk Lirası yalnızca bin Amerikan Dolarına tekabül ediyordu ${ }^{52}$.

$\mathrm{Bu}$ örneğin çarpıcı bir şekilde ortaya koyduğu gibi, hükmedilen manevi tazminata faiz yürütülmediği takdirde davacının mağdur olması genellikle

\footnotetext{
${ }^{50}$ ÜNLÜÇAY, a.g.m., s. 8 vd. Bu konuda örnek kararlar için bkz: "İdari Yargılama Usulünde, ilgililerin fazlaya ilişkin haklarını saklı tutarak tam yargı davası açabilmelerine olanak tanınmamıştır.” (Danıştay 6. Dairesinin 11.5.2000 tarih ve E. 1999/2712, K. 2000/2819 sayılı kararı, Danıştay Dergisi, Sayı 105, s. 340); "Davacının fazlaya ilişkin haklarını saklı tutarak açmış olduğu ilk tazminat davasında yaptırılan bilirkişi incelemesiyle saptanan zararın istemini aşan bölümünün tazmini istemiyle açtığı dava; idari yargıda, idari eylem veya işlemlerden doğan zararın tazmininin ancak süresi içinde açılacak davalar yoluyla istenebileceği, fazlaya ilișkin haklar saklı tutularak süresi geçirildikten sonra yeniden tam yargı davası açılmasına olanak bulunmadığı ..." (Danıştay 10. Dairesinin 15.5.1992 tarih ve E. 1991/2716, K. 1992/2050 sayılı kararı, Danıştay Dergisi, Sayı 86, s. 576); "Daha önce süresinde açılan davada fazlaya ilişkin hakların saklı tutulmasının yeni dava açma süresi bahşetmeyeceği" Danıştay 10. Dairesinin 10.6.1998 tarih ve E. 1996/1026, K. 1998/2451 sayılı kararı, BAL/KARABULUT/ŞAHIN, a.g.e., s. 232); "İdari yargıda, idari işlem veya eylemlerden doğan zararın tazmininin ancak süresi içinde açılacak davalar yoluyla istenebileceği fazlaya ilişkin haklar saklı tutularak süresi geçirildikten sonra yeniden tam yargı davası açılmasına imkân bulunmadı ğından davanın süre yönünden reddi gerektiği sonucuna ulaşılmıştır." (AYİM 2. Dairesinin, 29.9.1993 tarih ve E. 1993/408, K. 1993/398 say1l kararı, Zehreddin ASLAN/Kahraman BERK, İdare Hukuku ve İdari Yargıya İlişskin Temel Kanunlar, Güncellenmiş 3. Basım, Alfa, İstanbul, 2005, s. 283).

${ }_{51}^{51}$ Aynı yönde değerlendirmeler için bkz: ÜNLÜÇA̧ Y, a.g.m., s. 9.

52 GÖZLER, a.g.e., s. 1288.
} 
kaçınılmaz olmaktadır ${ }^{53}$. Bu itibarla, eşitsizlik ve adaletsizliklerin önüne geçmek için hükmedilen manevi tazminata faiz yürütülmesi bir zorunluluktur $^{54}$. Adli yarg1 yerlerinin uygulaması da öteden beri bu yöndedir ${ }^{55}$ ve bu uygulamanın idari yargıda da benimsenip uygulanmaması için hiçbir sebep görmüyoruz. Zira Couzinet'in de haklı olarak belirttiği gibi, her ne kadar Fransız Uyuşmazlık Mahkemesinin 1873 tarihli ünlü "Blanco" kararından beri idarenin sorumluluğunun özel hukuk alanındaki sorumluluktan farklı olduğu; kendine özgü ilke ve koşulları bulunduğu belirtilmekte ise de, bu demek değildir ki, sorumlulukla ilgili ortak prensip ve çözümler olmayacaktır ${ }^{56}$.

Nitekim sorumluluğun kendisi gibi, manevi zararların parayla tazmin edilebileceği de önce Özel Hukukta kabul edilmiş ve idari yargi yerleri de bunun etkisinde kalarak aynı yönde bir uygulama içine girmişlerdir ${ }^{57}$. Şu halde, adli yarg1 yerlerinin hükmettikleri manevi tazminata faiz de yürütmeleri yolundaki uygulamayı kabul etmemek için hiçbir neden görmüyoruz. İdari yarg1 yerlerinin, adli yarg1 yerleriyle karşılaştırıldığında daha düşük tutarda tazminata hükmediyor olmaları $\mathrm{da}^{58}$ bunu daha bir gerekli k1lmaktadır ${ }^{59}$.

Kanaatimizce, Danıştay da, eleştirdiğimiz bu içtihadından uzaklaşacak gibi görünmektedir. Gerçekten de, uzunca bir süre manevi tazminata faiz yürütülmesi taleplerini reddeden Danıştay, yakın zamanda ${ }^{60}$ aksi yönde kararlar tesis ederek, nihayet söz konusu içtihadından dönme işaretlerini vermeye başlamıştır. Nitekim 10. Dairenin, sonucu ve gerekçeleri itibariyle tamamen paylaştığımız, 25.03.2003 tarih ve E. 2002/4177, K. 2003/1089

\footnotetext{
${ }^{53}$ Yararlandığımız kaynakta, hükmedilen maddi ve manevi tazminata faiz yürütülüp yürütülmediğine dair bir açıklık olmamakla birlikte, Danıştay'ın bu konuda bilinen tutumu dikkate alınırsa, maddi tazminata faiz yürütüldüğü, buna karşllık manevi tazminata ise yürütülmediği rahatlıkla söylenebilir.

54 Ayn1 yönde bkz: ZABUNOGGLU, a.g.e., s. 276; ÖZGÜLDÜR, a.g.e., s. 361; ARMAĞAN, a.g.e., s. 312.

${ }_{56}^{5}$ HELVACI, a.g.e., s. 110-111.

${ }^{56}$ Jean- François COUZINET, “Cas De Force Majeure Et Cas Fortuit: Causes D’Exonération De La Responsabilité Administrative", Revue Du Droit Public, 1993 ( octobre-séptemre ), s. 1385.

57 DEGUERGUE, a.g.e., s. $421 \mathrm{vd}$.

${ }^{58}$ GÜRAN, a.g.m., s. 168; ZABUNOĞLU, a.g.e., s. 276. İdari yarg1 yerlerince hükmedilen tazminatın düşüklügü yänız ülkemizde değil, Fransa'da da eleştirilmektedir. Nitekim Danıștay'ın öyle bir rolü yahut görevi bulunmadığı halde, tazminata hükmederken kamusal gelirleri savurganca harcamış olmamaya özen göstererek oldukça düşük tutarda tazminata hükmettiği kaydedilmektedir. Bkz: DEGUERGUE, a.g.e., s. 432; GUETTIER, a.g.e., s. $135-136$.

${ }^{59}$ ZABUNOĞLU, a.g.e., s. 276.

${ }^{60}$ Ancak, tespit edebildiğimiz kadarıyla, nispeten eski tarihli sayılabilecek bir kararında Danıștay manevi tazminata dava tarihinden itibaren faiz yürütülmesi isteğini kabul etmiștir. Bkz: Danıştay 8. Dairesinin 24.12.1984 tarih ve E. 1982/1857, K. 1984/1618 sayılı kararı, Danıştay Dergisi, Sayı 58-59, s. 304.
} 
say1lı kararında şu gerekçelerle manevi tazminata faiz yürütülmesi talebi kabul edilmiştir:

"Mahkeme kararının hükmedilen manevi tazminata yasal faiz yürütülmesi isteminin reddine ilişkin kısmına gelince;

Manevi tazminat, patrimuanda meydana gelen bir eksilmeyi karşılamaya yönelik bir tazmin aracı olmayıp, manevi tatmin aracıdır. Başka türlü giderim yollarının bulunmayışı veya yetersiz kalışı, manevi tazminatın parasal olarak belirlenmesini zorunlu hale getirmektedir.

Manevi tazminata hükmedilmesi için kişinin fizik yapısını zedeleyen, yaşama ve kazanma gücünün azalması sonucunu doğuran olayların meydana gelmesi ve idarenin hukuka aykırı bir işlem veya eylemi sonucunda ağır bir elem ve üzüntünün duyulmuş olması veya şeref ve haysiyetinin rencide edilmiş bulunması gerekir.

Manevi zararın tazminine hükmedilirken ilgililerin sosyal ve ekonomik durumu dikkate alınarak olay nedeniyle duyduğu elem ve ızdırabın kısmen giderilmesini ifade edecek, idarenin hukuka aykırılığının ağırlığını ortaya koyacak ve hukuka aykırılığı özendirmeyecek bir miktarın belirlenmesi gerekmektedir.

Manevi tazminatın yukarıda belirtilen özellikleri dikkate alındığında, manevi zararın telafisi için hükmedilecek miktara idareye başvuru tarihinden itibaren 3095 sayılı Kanuni Faiz ve Temerrüt Faizine İlişkin Kanun uyarınca faiz yürütülmesini gerekli kılmaktadır..."61.

10. Daire, yine aynı tarihlerde ve tamamen aynı gerekçelerle ve fakat bu defa oy çokluğuyla aynı yönde karar almıştır ${ }^{62}$. Karara muhalif kalan üyenin muhalefet gerekçeleri, manevi tazminata faiz yürütülmemesi yönünde şimdiye kadar süre gelen yaklaşımın gerekçelerini genel olarak yansıttığından, bir karşılaştırma yapılmasına olanak sağlaması için aynen aktariyoruz:

"Bir maddi zararın giderilmesine yönelik açılan tam yargı davalarında tazminat faizi kişinin malvarlığındaki zararın oluştuğu an itibariyle karşılanması gerekirken, gecikerek ödenmesi karşısında bu gecikmeden dolayı para değerinde enflasyon nedeniyle meydana gelecek azalmayı karşılamaya yönelik olarak hükmedilmektedir.

${ }^{61}$ Danıştay Kararlar Dergisi, Sayı 2, s. 341-342; aynı yönde diğer kararlar için bkz: Danıștay 6. Dairesinin 16.4.2002 tarih ve E. 2001/1396, K. 2002/2298 sayılı kararı, Danıştay Kararlar Dergisi, Sayı 1, s. 247-249; Danıştay 6. Dairesinin 2001/1396Danıştay 6. Dairesinin 19.03.2004 tarih ve E. 2004/359, K. 2004/1691 sayılı kararı, Danıştay Kararlar Dergisi, Say1 5, s. 184.

${ }^{62}$ Danıştay 10. Dairesinin 25.02.2003 tarih ve E. 2001/323, K. 2003/703 say1lı kararı, Danıştay Kararlar Dergisi, Sayı 2, s. 342. 
Maddi zararlar malvarlığında meydana gelen ve para ile değerlendirilebilen bir azalmayı ifade ettiklerinden, bu azalma miktarının idare tarafından telafi edilmediği süre içinde ayrıca enflasyon nedeniyle de kayba uğrayacağı aşikârdır. Manevi zararlar ise malvarlığında meydana gelen somut bir azalma olmayıp, kişinin manevi varlığında ortaya çıkan olumsuzluklar olduğundan, manevi tazminat değerinin yargılama sonucu para olarak belirlenmesi zarara uğrayanı tatmin ve de bu zararı meydana getireni cezalandırma aracı olarak kullanılmasından kaynaklanmaktadır.

Bu itibarla, ilk defa yargı kararıyla para olarak değerlendirilebilen bir manevi tazminatın önceden davalı idarece belirlenmesi ve de ödenmesinin mümkün olmaması nedeniyle, ödenmede gecikmeden bahsedilemeyeceğinden kararın manevi tazminata faiz uygulanması gerektiği yolundaki kısmına katılmıyorum"63.

\section{ASKERİ YÜKSEK İDARE MAHKEMESİ'NIIN UYGULAMASI}

AYIM, kurulduğu tarih olan 1972 yılından 1975 yılına kadar, Danıştay içtihadının etkisinde kalarak, manevi tazminata faiz yürütülmesi taleplerini reddetmiştir ${ }^{64}$. $\mathrm{Bu}$ tarihten sonra ise, içtihat değiştirerek, olay tarihinden itibaren başlamak üzere faize hükmetmeye başlamış ve bu içtihadını da 1994 yılına kadar sürdürmüştür ${ }^{65}$. Kısa bir süre için (Ocak 1994-Şubat 1995) ${ }^{66}$ eski içtihadına dönen AYİM şu gerekçeyle faiz istemlerini reddetmeye başlamıştır:

“...Davacilar vekili manevi tazminata olay tarihinden itibaren faiz yürütülmesini talep etmiş ise de, Kurulumuzca davacıların gerek olay anında duydukları ve gerekse ömür boyu duyacakları acı ve 1stıraplarını karşılamak üzere takdir edilen manevi tazminat miktarı paranın karar sırasındaki alım gücü esas alınarak tespit edildiğinden davacının bu yoldaki taleplerinin reddi cihetine gidilmiştir..."

\footnotetext{
${ }^{63}$ Danıştay Kararlar Dergisi, Sayı 2, s. 344.

${ }^{64}$ Bkz: AYIM 3. Dairesinin 06.11.1973 tarih ve E. 1973/1265, K. 1973/708 say1l kararı ile 25.06.1974 tarih ve E. 1974/111, K. 1974/1316 sayılı karar1; Serdar ÖZGÜLDÜR, Askeri Yüksek İdaresi Mahkemesi Kararları Ișı̆ı̆ında Tam Yargı Davaları, Yetkin Yayınları, Ankara, 1996, s. 360.

65 ÖZGÜLDÜR, a.g.e., s. 360; GÖZLER, a.g.e., s. 1289; konuya ilişkin örnek kararlar için bkz: AYIM 2. Dairesinin 03.07.1986 tarih ve E. 1985/209, K. 1986/86 say1l kararı, AYİMD, Say1 7, Kitap: 2, s. 907; AYİM 2. Dairesinin 29.04.1992 tarih ve E. 1991/344, K. 1992/250 say1lı karar1, AYIMD, Say1 7, Kitap: 2, s. 933.

${ }^{66}$ GÖZLER, a.g.e., s. 1289.

${ }^{67}$ AYIM 2. Dairesinin 30.03.1994 tarih ve E. 1994/671, K. 1994/637 say1l karar1, AYIMDD, Say1 9, s. 661.
} 
Nihayet, anılan tarihten sonra faiz talepleri tekrar kabul edilmeye başlanmış ve fakat bu defa olay tarihinden itibaren değil, hüküm tarihinden ödeme gününe kadar geçen süreyi karşllamak için $^{68}$. Ancak, öyle görünmektedir ki, Yüksek Mahkeme Aralık 1998 yılından bu yana tekrar 1994 öncesi içtihadına geri dönerek, olay tarihinden itibaren geçerli olmak üzere faize hükmetmeye başlamıştır ${ }^{69}$. Ancak, bu yöndeki içtihatta da bir birlik ve kararlılık görülmemektedir. Örneğin, Askeri Yüksek İdare Mahkemesi Daireler Kurulu, 07.03.2002 tarih ve E: 2001/104, K. 2002/7 sayılı kararında ${ }^{70}$, aşağıdaki kararda yer alan gerekçeyle, oy çokluğuyla da olsa, olay tarihinden değil, hüküm tarihinden itibaren faiz işletilmesine hükmetmiştir:

“...Davac1 vekili manevi tazminata olay tarihinden itibaren yasal faiz yürütülmesini talep etmiş ise de; takdir olunan manevi tazminat miktarı paranın karar tarihindeki alım gücü olay tarihinden karar tarihine kadar geçen süredeki değişen sosyal ve ekonomik koşullar nazara alınarak davacının olay tarihindeki manevi zararlarının tamamını kapsayacak şekilde tespit ve takdir edildiğinden hükmolunan manevi tazminat miktarına karar tarihinden ödeme tarihine kadar yasal faiz uygulanmasına...”.

Askeri Yüksek İdare Mahkemesinin, deyim yerindeyse, kararsızlık gösteren çizgisi elbette ki manevi zarar ve onun karşıllı̆ 1 olan manevi

${ }^{68}$ Örneğin bir kararda şöyle denilmektedir: “...Davacının olay sebebiyle duyduğu ve ömür boyu duyacağı acı ve istırabını kısmen de olsa karşılayabilmek amacıyla davacıya uygun miktarda tazminat verilmesi kabul edilmiştir.

Davacı vekili manevi tazminata olay tarihinden itibaren yasal faiz yürütülmesini talep etmiş ise de; Kurulumuzca davacının bu sakatlanma olayı nedeniyle duyduğu ve ömür boyu duyacağı acı ve sstırabını karşılamak üzere takdir edilen manevi tazminat miktarı paranın karar sırasındaki alım gücü esas alınarak tespit edildiğinden davacı vekilinin olay tarihinden itibaren faiz yürütülmesi talebinin reddi cihetine gidilmiş, ancak takdir olunan manevi tazminat miktarı için karar tarihi olan 15 Mart 1995 tarihinden ödeme tarihine kadar yasal faiz yürütülmesine karar verilmiştir.” AYİM 2. Dairesinin 15.03.1995 tarih ve E. 1994/949, K. 1995/307 say1l kararı, AYİMD, Say1 10, s. 897; AYIM Daireler Kurulunun 06.11.1997 tarih ve E. 1997/1, K. 1997/114 sayılı kararı, AYIMMD, Say1 12, s. 1100. (Karar oyçokluğuyla verilmiş olup, muhalif kalan üyeler hüküm tarihinden değil, olay tarihinden itibaren faiz işletilmesi gerektiğini ileri sürmüşlerdir. Bkz: İbid, s. 11021104.)

${ }^{69}$ AYİM 2. Dairesinin 09.12.1998 tarih ve E. 1998/140, K. 1998/948 say1l karar1, AYİMD, Say1 13, s. 900; AYIM 2. Dairesinin 03.04.2002 tarih ve E. 2000/303, K. 2002/234 say1li kararı, AYIMD, Say1 17, Kitap: 2, s. 1100; AYİM 2. Dairesinin 13.06.2002 tarih ve E. 2000/600, K. 2002/569say1lı kararı, AYİMD Say1 17, Kitap: 2, s. 1103; fakat belirtelim ki, anılan kararlar oyçokluğuyla verilmiştir. Bazı üyeler, şu gerekçelerle karara muhalif kalmışlardır: "Takdir olunan manevi tazminat miktarı paranın karar tarihindeki alım gücü, olay tarihinden karar tarihine kadar geçen süredeki değişen sosyal ve ekonomik koşullar nazara alınarak ,davacıların olay tarihindeki manevi zararlarının tamamını kapsayacak şekilde tespit ve takdir edildiğinden, manevi tazminata olay tarihinden itibaren yasal faiz yürütülmesi isteminin reddine karar verilmesi, ancak karar tarihinden ödeme tarihine kadar yasal faiz yürütülmesi gerektiği görüşünde bulunduğumuzdan çoğunluğun aksi yöndeki kararına katılmıyoruz." AYIMMD, Sayı 13, s. 904.

${ }^{70}$ AYİMD, Say1 17, Kitap: 2, s. 1170. 
tazminat kavramlarının nitelikleri hakkında hâlâ yapılan tartışmaların somut bir sonucudur ${ }^{71}$. Fakat eğer Askeri Yüksek İdare Mahkemesi, olay tarihinden değil de tekrar hüküm tarihinden itibaren manevi tazminata faiz yürütmeye başlarsa, bu durumda genel idari yargı alanında kanunla gerçekleştirilmiş olan bir düzenlemeyi içtihat ile gerçekleştirmiş olmaktan öte bir şey yapmış sayllmaz.

Şöyle ki; 2577 sayılı İdari Yargılama Usulü Kanununun 10.6.1994 tarih ve 4001 sayılı Kanunla değişik 28. maddesinin 6. fikrasına göre, "tazminat ve vergi davalarında kararın idareye tebliğinden itibaren infazın gecikmesi sebebiyle idarece kanuni gecikme faizi ödenir.” İşte, getirilen bu düzenleme ile genel idari yarg1 yerlerince hükmedilen maddi ve/veya manevi tazminata, kararın idareye tebliğinden itibaren zaten kendiliğinden kanuni gecikme faizi işleyecektir ${ }^{72}$. Oysa 1602 sayılı Askeri Yüksek İdare Mahkemesinin aynı konuyu düzenleyen 63. maddesinde aynı yönde bir kural yer almadığından, mahkemece hüküm altına alınan manevi tazminata hüküm tarihinden itibaren faiz işletilmesi gereği böylece içtihatla karşılanmaya çalışılmıştır. Aradaki tek fark ise, IYUK kararın idareye tebliği tarihi tarihinden itibaren faiz yürütülmesini öngördüğü halde, AYİM bu yönde verdiği kararlarında bunun hüküm tarihinden itibaren olması gerektiğini kararlaştırmaktadır.

Gerçi, hükmedilen tazminata faiz yürütülmesi meselesi bir yönüyle Özel Hukuk alanında da tartışmalıdır; fakat tartışmanın parametreleri tamamen farklıdır. Daha önce de belirttiğimiz gibi, bir kere bu alanda hükmedilen tazminata faiz yürütülmesi meselesi tartışma konusu yapılmamaktadır ${ }^{73}$. Gerçekten de, Özel Hukuk öğreti ve uygulamasında da

\footnotetext{
${ }^{71}$ ÖZGÜLDÜR ise AYIMM'in zaman içinde değişkenlik gösteren içtihadını şöyle değerlendirmektedir: "Kendisini ve uygulamasını tanıtma konusunda ölçülü ve mütevazi bir çizgi izleyen AYİM, gerçekte tazminat hukuku ve tazminatın hesaplanması konularında yirmi yıldır 'ileri' ve 'çağdaş' bir çizgi içinde ve daima kendini aşma çabasılyla 'örnek' bir uygulamayı başlatmış, yürütmüş, ve halen de yürütmektedir...AYİM uygulamasının da tartışmaya açık ya da eksik birçok yönleri bulunabilir. Ancak, Anayasanın 125 nci maddesinin aydınlatıcı 1 ș̆ ğı dișında hiçbir yasal norma sahip olmayan idari sorumluluk alanında, salt yarattığı içtihatlarla bir belirsiz boşluğu neredeyse tamamen dolduran AYİM'in bu uygulamasının ve belirlediği ilke ve kriterlerin en azından diğer idari yargı organları açısından 'model' olabileceği inancındayız." Bkz: Serdar ÖZGÜLDÜR, "Idare Hukukunda Tazminat Hesabının Unsurları ve Hesaplama Yöntemi: AYİM Uygulaması", AYİMD, Say1 11, s.53-54.

72 Danıştay Kanunda sözü geçen "kanuni gecikme faizi”nin oranı olarak 19.12.1984 tarihinde yürürlüğe giren 3095 sayılı Kanuni Faiz ve Temerrüt Faizine İlişkin Kanunun 1. maddesinde öngörülen senelik faiz oranını almaktadır. Bkz: Turgut CANDAN, "İdari Yarg1 Kararlarının Uygulanması", İdari Yargı Paneli (11-12 Nisan 2003, Mersin), s. 252 vd.

${ }^{73}$ Gerçi gerek yasal düzenlemelerin farklı uygulamalara yol açması ve gerekse uygulamada bir birlik ve kararlılık bulunmaması nedeniyle, tazminata esas alınacak zarar miktarının belirlenmesinde hüküm anına itibar edilmesi halinde faiz işletilmesine gerek kalmayacağından, faiz yürütülmesinden kaynaklı problemlerin böylece daha kolay halledilebileceği de ileri sürülmektedir. Bkz: Kenan TUNÇOMAĞ, Borçlar Hukuku, Cilt I, Genel Hükümler, Üzerinde Çalışılmış Beşinci Bası, Fakülteler Matbaası, İstanbul, 1972, s. 296; HELVACI, a.g.e., s. 111.
} 
haksız fiilden kaynaklanan zararlarda uygulanacak faizin türü ve başlangıç zamanı konusunda fikir birliği bulunmamakla birlikte, bu alanda tartışmalı olan hususlar, idari yargı alanında yaşananlardan bir hayli farklıdır. Öyle ki, iki görüş arasındaki fark; bazı yazarların bu tür zararlara tazminat veya yargılama faizi adını verdikleri özel bir faiz türünün uygulanmasından yana olmaları; diğerlerinin ise bunun temerrüt faizi olmas1 gerektiğini düşünmelerinden ibarettir ${ }^{74}$.

Diğer bir deyişle, her iki görüş de tazminatın zararın doğduğu anda ödenmesi ve bunun sonucu olarak da zarar görenin tüm kaybının karş1lanması gerektiği biçiminde ortak bir çıkış noktasına sahiptirler. Ancak, ikinci görüş sahipleri, failin haksız fiil anında temerrüde düştüğünü kabul ederek bu durumda temerrüt faizinin uygulanması gerektiğini ileri sürmelerine karşılık; birinci görüş sahipleri, tazminatın henüz saptanmadığını, failin ödeme niyetinde olsa bile tazminat miktarını bilmediği için ödeme kabiliyetinden yoksun olduğunu, hatta muacceliyetin henüz gerçekleşmediğini ileri sürerek temerrüt faizinin uygulanamayacağını savunmaktadırlar ${ }^{75}$. Yargitay da gerek haksiz fiil ve gerekse sebepsiz zenginleşme hallerinde olay tarihinden itibaren temerrüt faizi işletilmesi gerektiği sonucuna varmaktadir ${ }^{76}$.

\section{SONUÇ}

Manevi zarar deyimi gerçek bir zararı değil, duyulan acı ve ruhi sarsıntıları ifade etmekle beraber; gerek bu duruma yol açan failin cezasız kalmaması ve gerekse mağdurun acı ve üzüntülerini hafifletmek için bir miktar tazminata hükmedilmesi gerektiği günümüzde artık tartışma konusu olmaktan çıkmıştır. Kuşkusuz, bir acının veya elemin maddi zararlar gibi parayla ölçülmesine imkân yoktur. Bu sebeple, manevi bir zararın şu veya bu miktardaki bir para ile giderilebileceği söylenemez. Kaldı ki, zamanı tersine çevirerek yaşanmış ve muhatabı üzerinde izlerini bırakmış bir olayı hiç yaşanmamış gibi bütün sonuçları ile birlikte silmeye olanak olmadığı da tartışmasızdır. Buna rağmen, manevi tazminata hükmedilmesi ile mağdurun manevi alanda uğramış olduğu yıkıntı, elem ve 1stırap belli bir ölçüde giderilmeye çalışılır. Çünkü Anayasa Mahkemesinin bir kararında da açıklandığı gibi, "para bugün için hâlâ mübadele aracı ve hesaplaşma birimi olarak fiyatların adlandırılmasında, borçların yerine getirilmesinde, eşya ve hizmet karş1lıklarının ödenmesinde, değerlerin servetlerin ölçülmesinde kullanılan en elverişli tek buluş olduğuna göre, manevi zararların

\footnotetext{
${ }_{75}^{74}$ HELVACI, a.g.e., s. 110.

${ }_{76}^{75}$ HELVACI, a.g.e., s. 111-112.

${ }^{76}$ HELVACI, a.g.e., s. 113 ve dipnot 338.
} 
değerlendirilebilmesinde ve karşılanmasında paradan yararlanmaktan kaçınılamayacağı ortadadır. Para, bu alanda eksiktir, yetersizdir; ancak daha iyisi ve elverişlisi bulunmadığ 1 içindir ki aracılığından vazgeçilememektedir" ${ }^{\prime 77}$.

İşte manevi tazminata para olarak hükmedilmesini gerekli k1lan bu gerekçeler, ona faiz yürütülmesini de gerektirmektedir. Bu itibarla, manevi tazminata faiz yürütülmesi hakkındaki Danıştay içtihadının değişme işaretleri vermesini olumlu bir gelişme olarak değerlendiriyoruz. Zira bütün tartışmalı niteliğine rağmen, sonuçta manevi zarar karşılığı olarak tazminata hükmedilebildiğine göre, hükmedilen bu tazminata faiz yürütülmesi de tabiidir. Aksi takdirde, yani hem tazminata hükmetmek hem de bu tazminatın gerçek bir zararın karşı1lığı olmadığı; başka giderim yollarının olmayışı veya yetersizliği nedeniyle mağduru teselli etmek için verilen sembolik bir para olduğunu ve dolayısıyla faiz yürütülmesine yer olmadığını söylemek, hem tutarsızlı içerir ve hem de birtakım adaletsizliklere yol açması kaçınılmaz olur.

Aynı şekilde, manevi zararın hüküm tarihi itibariyle değerlendirilmiş olduğu ve bu itibarla davacının bütün zararının karşılandığ 1 gerekçesiyle hükmedilen manevi tazminata faiz yürütülmesine gerek olmadığ 1 şeklindeki yaklaşımda da isabet görmüyoruz. Zira her şeyden önce, davacı davasını açarken hükmün ne zaman verileceğini bilemeyeceğinden talep edeceği tazminat tutarını, haklı olarak, hükmün verileceği tarihe göre değil, davasını açacağı güne göre belirleyecektir. Çünkü davacı talebinin reddedilen kısmı üzerinden davalı idareye vekâlet ücreti ödemek zorunda kalmamak için, olabildiğince mahkemenin kabul edebileceği bir meblağ etmek zorundadır. Davacı, bunun yanında, hâkimin taleple bağlılı̆̆ını göz önünde bulundurarak gerçek zararının altında bir meblağ talep etmemeye de dikkat etmek zorundadır; çünkü; yargılama sırasında gerçek zararın talep edilenden fazla olduğu anlaşılsa dahi hâkimin taleple bağlı olması kuralı, talep edilenden fazlasına hükmedilmesine engel teşkil etmektedir. Hal böyle olunca, davacının herhangi bir hak kaybına uğramamak için ne denli güç bir durumla karşı karşıya bulunduğu ortadadır. Deyim yerindeyse, davacı talebinin reddedilen kısmı üzerinden vekâlet ücreti ödeme zorunda kalması baskısı ile zararı daha fazla olsa bile taleple bağlılık nedeniyle ancak talep ettiği tutara hükmedilebilmesi olgusu arasında sıkışıp kalmaktadır. Bütün bunlara, davaların geç karara bağlanıyor olması olgusu da eklendiğinde ${ }^{77}$ Anayasa Mahkemesinin 11.02 .1969 tarih ve E. 1968/ 33, K. 1969/ 12 say1l kararı, AMKD,
Say1 7, s. 242. 
davacının karşı karşıya bulunduğu güçlüğün boyutları daha iyi anlaşılabilecektir ${ }^{78}$.

Kamu gücünün neden olduğu zararı karşılaması gereği Hukuk Devletinin gereklerinden biri olarak görüldügüne göre, yargı yerlerinin de bunu göz önünde bulundurarak zarar göreni mağdur etmeyecek çözümler üretmeleri gerekir. İşte, hükmedilen manevi tazminata istem üzerine faiz yürütülmesi de bu çözümlerden biri olarak görülmelidir.

Sonuç olarak, manevi zararların parayla ölçülüp değerlendirilmesindeki zorluk açık olmakla birlikte, kaçınılmaz da bulunduğuna göre, hükmedilen manevi tazminata idareye başvuru tarihinden itibaren faiz işletilmesi hakkaniyete ve adalete uygun düşecektir.

\section{KAYNAKÇA}

AKILLIOĞLU, Tekin: "Gözlemler: Yönetsel Yargıda Manevi Giderim ve Bilgi Hukuku Gelişmesi”, Amme İdaresi Dergisi, Cilt 22, Sayı 2, 1989.

ALPASLAN, Reha T.: "Manevi Tazminat Konusuna Genel Bakış", Adalet Dergisi, Cilt 58, 1967.

ARMAĞAN, Tuncay: İdarenin Sorumluluğu ve Tam Yargı Davaları, Seçkin Yayınevi, Ankara, 1997.

ASLAN, Zehreddin/BERK, Kahraman: İdare Hukuku ve İdari Yargıya İlişkin Temel Kanunlar, Güncellenmiş 3. Basım, Alfa, İstanbul, 2005.

ATAAY, Aytekin: Borçlar Hukukunun Genel Teorisi, Birinci Yarım, Üçüncü Bas1, Fakülteler Matbaası, İstanbul, 1981.

ATAY, E. Ethem/ODABAŞI, Hasan/GÖKCAN, Hasan Tahsin: Teori ve Yargı Kararları Işı̆ı̆ında İdarenin Sorumluluğu ve Tazminat Davaları, Seçkin, Ankara, 2003.

BAL, Yakup/ŞAHIN, Yahya/KARABULUT, Mustafa: Danıştay 10. Dairesinin Tazminat Davalarına İlişkin Seçilmiş Kararları, Seçkin Yayınları, Ankara, 2003.

BALTA, Tahsin Bekir: İdare Hukukuna Giriş I, TODAİE Yayını, 1968/ 1970.

DELCROS, Xavier/DELCROS, Bertrand: Fransa ve İngiltere'de İdarenin Sorumluluğu, (Çeviren: Turgut CANDAN) Danıştay Başkanlığı Yayını, Ankara, 1984.

CANDAN, Turgut: "İdari Yargı Kararlarının Uygulanması", İdari Yargı Paneli (11-12 Nisan 2003, Mersin).

\footnotetext{
${ }^{78}$ Nitekim Danıştay'ın bir kararında bu duruma işaret edilmiştir: "Ayrıca, yargılama sürecinin uzun sürmesi ve ülkemizde yaşanan yüksek enflasyon da dikkate alındığında, manevi tazminata da tazminat davasının açıldığı gün olan 18.10.1996 gününden itibaren yasal faize hükmedilmesi gerekmektedir." Bkz: Danıştay 6. Dairesinin 16.4.2002 tarih ve E. 2001/1396, K. 2002/2298 sayılı kararı, Danıştay Kararlar Dergisi, Sayı 1, s. 249.
} 
CHAPUS, René: Responsabilité Publique et Responsabilité Privé (Responsabilité), LGDJ, Paris, 1957.

CHAPUS, René: Droit Administratif Général, Tome I (Droit Administratif), 11. édition, Montchrestien, Paris, 1997.

COUZINET, Jean- François: "Cas De Force Majeure Et Cas Fortuit: Causes D’Exonération De La Responsabilité Administrative”, Revue Du Droit Public, 1993 (octobre-séptemre).

DARCY, Gilles: La Responsabilité De l'Administration, Dalloz, Paris, 1996.

DEGUERGUE, Maryse: Jurisprudence Et Doctrine Dans L'Élaboration Du Droit De La Responsabilité Administrative, LGDJ, Paris, 1994.

DURAN, Lûtfi: Türkiye İdaresinin Sorumluluğu, TODAİE Yayını, Ankara, 1974.

EREN, Fikret: Borçlar Hukuku Genel Hükümler, Tıpkı 7. Baskı, Beta, İstanbul, 2001.

ESIN, Yüksel: Danıştay'da Açılacak Tazminat Davaları, İkinci Kitap, Esas, Ankara, 1973.

GİRITLİ, İsmet/BİLGEN, Pertev/AKGÜNER, Tayfun: İdare Hukuku, Der Yayınları, İstanbul,2001.

GÖNEN, K. Eren: “İdari Yargıda Manevi Tazminat Meselesi”, Danıştay Dergisi, Sayı 108.

GÖZLER, Kemal: İdare Hukuku, Cilt II, Ekin Kitabevi, Bursa, 2003.

GÖZÜBÜYÜK, A.Şeref/TAN, Turgut: İdare Hukuku, Cilt: 1, Genel Esaslar Güncelleştirilmiş 2. Bası, Turhan Kitabevi, Ankara, 2001.

GUETTIER, Christophe: La Responsabilité Administrative, LGDJ, Paris, 1996.

GÜNDAY, Metin: İdare Hukuku, 9. Baskı, İmaj Yayıncılık, Ankara 2004.

GÜRAN, Sait: “Türk İdare Hukukunda Tazminat Miktarının Saptanması”, Sorumluluk Hukukunda Yeni Gelişmeler III. Sempozyumu, Ankara, 1213 Mayıs 1980, IÜHFY, İstanbul, 1980.

GÜRSOY, Kemal Tahir: "İdarenin Sorumluluğuna İlişkin İlkelerde Son Gelişmeler ve İsviçre Hukukunda İdarenin Hukuki Sorumluluğunun Ana Hatları" (Sorumluluk), Sorumluluk Hukukunda Yeni Gelişmeler III. Sempozyumu, Ankara, 12-13 May1s, 1980, İÜHFY, İstanbul, 1980.

GÜRSOY, Kemal Tahir: "Manevi Zarar ve Tazmini” (Zarar), AÜHFD, Cumhuriyetin 50. Yılına Armağan, Cilt XXX, sayı 1-4, 1973.

HELVACI, Mehmet: Borçlar ve Ticaret Kanunu Bakımından Para Borçlarında Faiz Kavramı, Beta, İstanbul, 2000.

KILIÇOĞLU, Ahmet: "Manevi Tazminatın Hukuksal Niteliğii" Ankara Barosu Dergisi, 1984/ 1.

KILIÇOĞLU, Ahmet: Borçlar Hukuku Genel Hükümler, 2. Bası, Turhan Kitabevi, Ankara, 2002. 
KOCAYUSUFPAŞAOĞLU, Necip: "Kişilik Haklarını Koruyan Manevi Tazminat Davasına İlişkin Yeni Gelişmeler", Sorumluluk Hukukunda Yeni Gelişmeler I. Sempozyumu (Ankara, 21-22 Ekim 1977), Fakülteler Matbaas1, İstanbul, 1980.

LACHAUME, Jean-François: Les Grandes Decision De La Jurisprudence, Onziéme édition, Puf, Paris, 1997.

OZANSOY, Cüneyt: Tarihsel ve Kuramsal Açıdan İdarenin Kusurdan Doğan Sorumluluğu, (Basılmamış Doktora Tezi, Ankara Üniversitesi Sosyal Bilimler Enstitüsü, Ankara, 1989).

ÖZGÜLDÜR, Serdar: Askeri Yüksek İdaresi Mahkemesi Kararları Işığında Tam Yargı Davaları, Yetkin Yayınları, Ankara, 1996.

ÖZGÜLDÜR, Serdar: "İdare Hukukunda Tazminat Hesabının Unsurları ve Hesaplama Yöntemi: AYİM Uygulaması", AYIMDD, Sayı 11.

POIROT-MAZERES, Isabelle: "La Notion De Préjudice En Droit Administratif Français", Revue Du Droit Public, 1997.

PAILLET, Michel: La Responsabilité Administrative, Dalloz, Paris, 1996.

REISOĞLU, Safa: Borçlar Hukuku Genel Hükümler, Değişiklik ve İlavelerle Onuncu Bask1, Beta, İstanbul, 1995.

RIVERO, Jean / WALINE, Jean: Droit Administratif, 20. édition, Dalloz, Paris, 2004.

TEKINAY, Selahattin Sulhi /AKMAN, Sermet/BURCUOĞLU, Haluk/ALTOP, Atilla: Borçlar Hukuku Genel Hükümler, Yeniden Gözden Geçirilmiş ve Genişletilmiş Yedinci Baskı, Filiz Kitabevi, İstanbul, 1993.

TUNÇOMAĞ, Kenan: Borçlar Hukuku, Cilt I, Genel Hükümler, Üzerinde Çalışılmış Beşinci Bası, Fakülteler Matbaası, İstanbul, 1972.

ÜNLÜÇAY, Mehmet: "İdarenin Tazmin Borcu ve Enflasyon Olgusu”, Danıştay Dergisi, Say1 94.

YAYLA, Yıldızhan: İdare Hukuku I, Gözden Geçirilmiş ve Genişletilmiş İkinci Bası, Filiz Kitabevi, İstanbul, 1990.

ZABUNOĞLU, Yahya K.: İdari Yargı Hukuku Dersleri, (Ankara, 1980-1981, Teksir ).

ZEN-RUFFINEN, P.: "İsviçre Sorumluluk Hukukunda Destekten Yoksun Kalma Tazminatı ve Manevi Tazminat Konusunda Yeni Gelişmeler", (Çeviren: Haluk BURCUOĞLU), İstanbul Barosu Dergisi, Cilt 59, Sayı 4-5-6, 1985. 